\title{
doispontos:
}

\section{Kant e a metafísica "crítica" da natureza}

\author{
Diego Kosbiau Trevisan \\ diegokosbiau@hotmail.com \\ Johannes Gutenberg-Universität, Mainz, Alemanha / Universidade de São Paulo (USP), São Paulo, SP
}

\begin{abstract}
Resumo: O objetivo do artigo é examinar os Primeiros Princípios Metafísicos da Ciência da Natureza de Kant, obrachave para a interpretação das filosofias da natureza do idealismo alemão, no interior d' 'A Arquitetônica da Razão Pura", a saber, como uma metafísica aplicada da substância corporal. Para tanto será inicialmente discutida a distinção, feita no prefácio à obra, entre uma parte transcendental e outra metafísico-específica da metafísica da natureza, surgindo aqui a concepção de matéria enquanto movente no espaço como conceito empírico mínimo para a constituição do objeto de uma metafísica da substância corporal. Na sequência, a oposição entre princípios transcendentais e princípios metafísicos será abordada como crucial para compreender como os princípios transcendentais da Crítica da Razão Pura se transformam nos princípios da física newtoniana. Por fim, analisase como a metafísica da natureza exemplifica a ideia de uma realização dos princípios transcendentais como passagem para a empiria.
\end{abstract}

Palavras-chave: Kant; ciência da natureza; metafísica; arquitetônica; física; matéria.

\section{Kant and the 'critical' metaphysics of nature}

Abstract: This paper aims to discuss Kant's Metaphysical Foundations of Natural Science, a pivotal work for the interpretation of the philosophies of nature in German idealism, as a disciplin contained in the 'Architectonic of Pure Reason', that is, as an applied metaphysics of corporeal substance. In order to do so we initially discuss the distinction made in the preface to the work between a transcendental and a metaphysical-specific part of metaphysics of nature. As result we come to the conception of matter, taken as something moveable in space, as a minimal empirical concept for constituting the object of a metaphysics of corporeal substance. Further the opposition between transcendental and metaphysical principles is addressed as a key for understanding how the transcendental principles of the Critique of Pure Reason become the principles of Newtonian physics. Finally, we analyse how the metaphysics of nature exemplifies the idea of realization of the transcendental principles understood as the transition to the empirical realm.

Keywords: Kant; science of nature; metaphysics; architectonic; physics; matter.

Durante toda sua produção filosófica, Kant ocupou-se intensa e continuamente com a ciência de seu tempo. Já em sua primeira obra, Os Pensamentos sobre a Verdadeira Estimativa das Forças Vivas, publicada em 1747, quando contava apenas 23 anos, Kant iniciava uma intensa reconsideração e reinterpretação crítica da ciência natural de sua época, posicionando-se criticamente contra leibnizianos e cartesianos ao mesmo tempo em que absorvia progressivamente a influência de Newton e, de modo geral, da filosofia experimental e ciência natural de então ${ }^{2}$. Já no período crítico, a obra em que Kant expõe de modo mais inequívoco as fundações filosóficas da física newtoniana e que representa, de resto, um esforço notável de aplicação de resultados da Crítica da Razão Pura a um âmbito específico de objetos são os Primeiros 
Princípios Metafísicos da Ciência da Natureza (doravante PPMCN), publicados em 1786, obra com a qual, segundo Hegel, o "conceito de uma filosofia da natureza foi redescoberto" (HEGEL, 2001, $\$ 262)^{3}$.

Não deve ser decerto menosprezada a influência e repercussão que os $P P M C N$ receberam nas filosofias idealistas pós-kantianas. À parte controvérsias sobre o fundamento e a completude do sistema crítico, levantadas pela tentativa kantiana de aplicar sua filosofia transcendental à natureza física, destacamse, entre outros, os ataques de Schelling à impossibilidade de uma derivação a priori dos princípios da química com base na consideração matemático-mecânica dos $P P M C N^{4}$, bem como a crítica de Hegel ao dinamismo kantiano, o qual impossibilitaria, contrariamente à intenção de Kant nos PPMCN, uma construção concreta do conceito de matéria ${ }^{5}$. Por mais interessantes e significativas que sejam tais polêmicas per se e em suas implicações para o desenrolar da filosofia idealista, o fato é que uma avaliação justa e precisa da filosofia crítica da natureza de Kant somente pode ser feita se, antes de qualquer outra coisa, seja compreendido o lugar sistemático preciso que os princípios de uma física racional ocupam no sistema geral da filosofia kantiana. No erro de desconsideração desse preceito interpretativo - numa visão contemporânea - elementar incorrem, curiosamente, tanto pós-kantianos quanto neo-kantianos ${ }^{6}$. $O$ objetivo de fundo do presente artigo é justamente empreender um esforço de reconsideração do lugar sistemático dos PPMCN no sistema kantiano?.

Os PPMCN são erigidos sob uma dupla égide: os princípios da física newtoniana e uma nova metafísica kantiana proposta segundo um modificado modelo racionalista, que situava a física no quadro de uma cosmologia e subordinava-a à ontologia como metaphysica generalis ${ }^{8}$. Kant concebe uma Metafísica da Natureza como uma filosofia racional a priori que, utilizando-nos de uma expressão encontrada nas Lições de Metafísica Mrongovius e Dohna, se caracteriza como uma metafísica teórica aplicada (V-Met/Mron AA 29: 750-751; V-Met/Dohna AA 28: 617) 9 que toma por objeto a natureza como o conjunto dos objetos dos sentidos. Trata-se, aqui, da construção de um sistema metafísico, isto é, racional, a priori e por meros conceitos, que arrola as leis e os princípios que regulam os objetos naturais tomados como objetos dos sentidos externo e interno, ou seja, respectivamente uma psicologia racional (que, na realidade, caracteriza-se como um saber aparente, incapaz da sistematização exigida por toda e qualquer disciplina metafísica) e uma física racional de matriz newtoniana caracterizada como o conjunto sistemático das leis que determinam, de forma matemática, a matéria como um movente no espaço. Nos PPMCN, Kant inclui no interior da Metafísica da Natureza uma parte transcendental ao lado de uma ciência natural metafísica particular (MAN AA 04: 469-470). Não deixemos, no entanto, que os termos enganem: trata-se de um e mesmo projeto de metafísica aplicada, que conta com um momento transcendental de fundamentação das condições de possibilidade da objetividade do conhecimento em geral, e um momento metafísico particular que acolhe um elemento empírico específico necessário para que seja constituído um objeto determinado, ao qual são aplicados os princípios estabelecidos na etapa transcendental anterior.

De modo a esclarecer e desenvolver o que acima foi posto de forma ainda sinóptica, trataremos inicialmente a já mencionada distinção realizada nos PPMCN entre uma parte transcendental, onde se cristalizam as exigências de necessidade e apodicticidade atribuídas a toda disciplina metafísica, e uma metafísica-particular, em que os princípios discernidos anteriormente são aplicados ao objeto específico de um âmbito da experiência (1). Neste último momento surge o conceito de matéria como o conceito empírico de um objeto dos sentidos externos, em relação ao qual, portanto, ocorre o procedimento de aplicação (2). Na sequência, veremos como está operante aqui uma distinção mencionada por Kant na Introdução à Crítica da Faculdade de Julgar entre princípios transcendentais e princípios metafísicos. Através desse expediente conceitual, compreende-se, por exemplo, em que o princípio de causalidade 
discutido no "Sistema de Princípios" da Crítica da Razão Pura se distingue da segunda lei da mecânica ou lei de inércia (3). Por fim, discutiremos o modo como os princípios transcendentais, estabelecidos na etapa propedêutica de certificação das condições de objetividade do conhecimento, são realizados ao encontrarem seus correlatos metafísicos que os aplicam à experiência efetiva, extraindo daí algumas reflexões sobre a natureza da filosofia transcendental (4).

\section{A PARTE TRANSCENDENTAL E A PARTE METAFÍSICA DA METAFÍSICA DA NATUREZA.}

Kant concebe sua física racional ou doutrina racional da substância corpórea como uma disciplina metafísica cujos princípios não podem ser extraídos da experiência, mas que - e em conformidade com a revolução copernicana posta em movimento pela Crítica da Razão Pura - são dispostos de forma $a$ priori pela atividade sintética do sujeito. Nesse sentido, é instrutivo comparar o procedimento atuante, segundo Kant, na física e na química. Na Introdução à Metafísica dos Costumes, embora já reconhecendo a potencial revolução na ciência química ensejada pelos então recentes trabalhos de Lavoisier, Kant opõe a universalidade estrita da física racional à mera generalidade indutiva dos princípios químicos. A ciência racional da natureza, possível apenas na física, deve ser contraposta às disciplinas que, como a química, obtêm seus enunciados de forma meramente indutiva, confiando, para isso, nos testemunhos fornecidos pela experiência e generalizados sob a pretensa forma de leis universais acerca do comportamento de determinados fenômenos. Embora a física em sua parte empírica (ou seja, a ciência empírica da natureza) possa, a exemplo do que ocorre na química, acolher princípios extraídos da observação da natureza, estas proposições de universalidade meramente indutiva devem estar, em última instância, fundadas em leis a priori caso se deseje com ela constituir uma "genuína ciência":

[A física] pode aceitar (ao menos quando se trata, para ela, de preservar do erro suas proposições) vários princípios como universais a partir do testemunho da experiência, ainda que este último, se tem de valer universalmente em sentido estrito, tenha de ser derivado de fundamentos a priori, assim como Newton admitiu como fundado na experiência o princípio da igualdade de ação e reação na influência recíproca dos corpos e o estendeu, não obstante, à totalidade da natureza material. Os químicos vão ainda mais longe e fundamentam inteiramente na experiência suas leis mais universais de união e separação das matérias por meio de suas próprias forças, confiando tanto em sua universalidade e necessidade, porém, que não temem a descoberta de um erro os experimentos nelas apoiados (MS AA 06: 215; grifos nossos).

A universalidade obtida pelos químicos é ilusória ou, na melhor das hipóteses, precária: essas regras gerais de comportamento de determinados fenômenos não são, na realidade, leis da natureza que fundam a cientificidade da disciplina que sobre elas repousa, constituindo-se, antes, como uma simples constatação de certas regularidades sem o caráter necessário e apodítico exigido em qualquer ciência que seja digna dessa designação:

Ciência genuína só pode chamar-se aquela cuja certeza é apodítica; o conhecimento que unicamente pode conter certeza empírica só impropriamente se pode chamar saber (...). Se os fundamentos e princípios são nela [ciência] apenas empíricos, como, por exemplo, na química, e se as leis, em virtude das quais se explicam, mediante a razão, os fatos dados, são simplesmente leis da experiência, não comportam então nenhuma consciência da sua necessidade (não são apoditicamente certas) e, por isso, a totalidade não merece, em sentido estrito, o nome de ciência; pelo que a química se devia chamar antes arte sistemática, e não ciência (MAN AA 04: 468).

A física racional, pelo contrário, é uma genuína ciência da natureza, cujas leis e princípios são racionais 
e fundados de modo a priori. Ora, a própria noção de natureza pressuposta (trata-se, lembremos, de uma metafísica da natureza corpórea ou pensante) envolve "o conceito de leis e este implica, por sua vez, o conceito da necessidade de todas as determinações de uma coisa, inerentes à sua existência” (MAN AA $04: 468)^{10}$. A necessidade exigida somente pode ser obtida através da parte pura dessa ciência, aquela que expõe, sem depender de testemunhos fornecidos pela experiência, os princípios a priori que exprimem a regularidade e universalidade ligadas ao conceito mesmo de uma natureza em geral como o conjunto ordenado dos fenômenos dados aos sentidos internos ou externos.

Toda a ciência natural genuína precisa, pois, de uma parte pura, na qual se deve fundar a certeza apodítica, que a razão nela busca; e visto que esta, segundo seus princípios e em comparação com os que são apenas empíricos, é inteiramente diversa, é da maior utilidade, mais ainda, em virtude da natureza da coisa, é um dever imprescindível, relativamente ao método, expor essa parte em separado e sem qualquer mescla com a outra (MAN AA 04: 469).

Em relação ao capítulo sobre "A Arquitetônica da Razão Pura", Kant altera ligeiramente os momentos em que consistiria essa parte pura da ciência da natureza, ou ainda, essa Metafísica da Natureza como a "genuína ciência da natureza" ${ }^{1}$. Agora, ao invés de uma "filosofia transcendental" entendida como ontologia e uma "fisiologia da razão pura" concebida como o saber metafísico de uma classe determinada de objetos de uma intuição possível ${ }^{12}$, surgem respectivamente uma "parte transcendental e uma "ciência natural metafísica particular". Em suma, a Metafísica da Natureza, a parte pura da ciência da natureza,

pode, porém, ou a) tratar, mesmo sem relação a qualquer objeto determinado da experiência (por conseguinte, de modo indefinido em relação à natureza desta ou daquela coisa do mundo sensível) das leis que tornam possível o conceito de uma natureza em geral - trata-se da parte transcendental da metafísica da natureza; ou b) então ocupa-se de uma natureza específica desta ou daquela espécie de coisas, de que se forneceu um conceito empírico mas, no entanto, de maneira que, afora o que reside neste conceito, nenhum outro princípio empírico se empregue para o conhecimento das mesmas (por exemplo, ela toma como fundamento o conceito empírico de uma matéria, ou de um ser pensante, e busca o âmbito do conhecimento que a razão é capaz a priori acerca destes objetos): uma tal ciência deve, pois, chamar-se sempre metafísica da natureza, a saber, da natureza corporal ou da natureza pensante; mas, então, não é uma ciência natural metafísica universal (allgemeine metaphysische Naturwissenschaft), mas sim específica (besondere metaphysische Naturwissenschaft) (física e psicologia), na qual aqueles princípios transcendentais são aplicados aos dois gêneros de objetos dos nossos sentidos (MAN AA 04: 469-470; grifos nossos).

Desse modo, a parte transcendental da Metafísica da Natureza assemelha-se à ontologia ou filosofia transcendental discutida na "Arquitetônica"; trata-se, aqui, da parte da ciência pura da natureza que contém os princípios transcendentais que tornam primeiramente possível o conceito de uma natureza em geral como o conjunto regulado por leis de todas as coisas que podem ser um objeto em geral dos nossos sentidos, ou seja, a totalidade dos fenômenos ordenados segundo leis a priori, ou ainda, o mundo sensível, sem que ainda se diferenciem objetos do sentido externo ou interno - em outras palavras, se se trata da natureza corpórea ou pensante específica ${ }^{13}$. Esse momento transcendental, assim, corresponde à primeira parte da metafísica, a "ontologia" crítica reconfigurada em analítica transcendental, que investiga os conceitos e princípios que determinam as propriedades de um objeto em geral, tomado, contudo, sob a restrição "crítica" de ser um objeto em geral pertencente ao conceito formal de natureza enquanto o conjunto de coisas que podem ser apresentadas aos sentidos externo e interno numa ordenação conforme a leis. Vejamos uma das muitas definições kantianas de ontologia "crítica":

A ontologia é a ciência (enquanto parte da metafísica) que constitui um sistema de todos os conceitos 
do entendimento e dos princípios, mas só na medida em que se referem a objetos que podem ser dados aos sentidos e, portanto, justificados pela experiência (FM AA 20: 260; grifos nossos).

A segunda parte da Metafísica da Natureza, a "ciência natural metafísica específica”, divide-se segundo os possíveis tipos de objetos dados aos sentidos: o objeto dos sentidos externos ou o objeto do sentido interno. Assim como ocorria na fisiologia imanente da razão pura discutida na "Arquitetônica", nesse momento considera-se a natureza particular de uma espécie determinada de objeto em geral que pode ser dado aos sentidos: trata-se seja da natureza específica do objeto dos sentidos externos, a matéria ou o ser extenso, seja da natureza específica do objeto do sentido interno, a alma ou o ser pensante. $\mathrm{O}$ procedimento de determinação das propriedades de cada um desses objetos é realizado através da aplicação dos princípios transcendentais ao conceito empírico seja de matéria, seja de alma.

\footnotetext{
À parte teórico-dogmática da metafísica pertence igualmente a doutrina racional geral da natureza, isto é, a filosofia pura sobre os objetos dos sentidos, os dos sentidos externos, ou seja, a doutrina racional dos corpos, ou do sentido interno, a doutrina racional da alma, pelo que se aplicam os princípios da possibilidade de uma experiência em geral a uma dupla espécie de percepções, sem pôr nenhum outro fundamento empírico além da mera existência de semelhantes objetos (FM AA 20: 285; grifo nosso).
}

Como Kant esclarece no prefácio aos PPMCN, nessa etapa a Metafísica da Natureza deve recorrer à matemática para que o conceito correspondente a cada um desses objetos seja construído na intuição, fazendo com que se passe da possibilidade para a existência dos mesmos, conforme se exige no conceito próprio de uma natureza corpórea ou pensante - como já mencionado, esta última é excluída de uma Metafísica da Natureza por não ser possível aplicar de modo completo a matemática a seu objeto ${ }^{14}$.

Desse modo, no restante de seus PPMCN, Kant expõe sua metafísica aplicada da substância corpórea ${ }^{15}$, na qual são aplicados os princípios transcendentais ao conceito empírico de matéria com auxílio do fio condutor das categorias:

Diferentemente da parte transcendental da metafísica da natureza, os $P P M C N$ tratam não das condições de
possibilidade da experiência de uma natureza em geral, portanto não de uma natureza extensa em geral, mas
antes de como pode ser-nos dada uma natureza cujas leis universais já conhecemos pois são constituídas
enquanto tais através das categorias e princípios do entendimento puro. E a metafísica específica é a
aplicação dos princípios transcendentais aos objetos dos sentidos externos, pois ela determina o caráter
igualmente empírico de uma natureza extensa dado através do conceito de matéria (HOPPE, 1969, p. 43).

Terminemos essa seção explicitando o aparente paradoxo da tarefa: a ciência pura da natureza, mais particularmente a sua parte específica sobre a substância corpórea, acolhe um conceito empírico, a matéria, do qual busca extrair de modo a priori certas leis, as leis do movimento, que são - pela sua definição mesma apontada no início como a pertencente a uma ciência "genuína" da natureza - universais e necessárias em sentido estrito. Como, contudo, Kant pode fazê-lo? De que maneira é possível determinar de forma a priori, ou seja, sem tomar o "testemunho da experiência" como fundamento, o comportamento e as determinações de algo que somente pode ser dado empiricamente? São as dificuldades próprias à definição do conceito de matéria que se apresentam nesse momento dos PPMCN.

\section{O CONCEITO EMPÍRICO DE MATÉRIA.}

Os PPMCN têm como objetivo definir as leis universais que regulam a matéria e a determinam como 
um movente no espaço. A exemplo do que ocorre no restante da metafísica aplicada, na metafísica da substância corporal trata-se de realizar uma passagem do âmbito transcendental para o do empírico. Ou, dito de forma mais adequada, "parcialmente empírico": para Kant, apesar de o conceito de matéria ser um conceito empírico, dele é possível discernir leis de modo completamente a priori, sem que, para isso, se dependa da experiência ou se passe para uma ciência empírica da natureza ${ }^{16}$.

Konrad Cramer interpreta o conceito de matéria como um conceito "a priori não puro", isto é, um conceito que

precisa ser interpretável, por um lado, como não 'abstraído da experiência' e, nesse sentido preciso, como um conceito a priori, e, por outro lado, como um conceito referido, de uma forma específica, à intuição empírica e, nesse sentido preciso, como conceito não-puro (CRAMER, 1989, p. 154).

Já Michael Friedman discute o aparentemente contraditório conceito de matéria ressaltando a necessidade da "transição" ou "passagem" entre os níveis de pureza discutida acima:

os Primeiros Princípios Metafísicos da Ciência da Natureza são trazidos a uma conexão a priori, por assim dizer, com a filosofia transcendental da Crítica por meio de uma transição do conceito puro de matéria, como a descrição do espaço na intuição pura, para o conceito empírico de matéria, como a determinação de um objeto no espaço na intuição empírica (FRIEDMAN, 2001, p. 341).

Nas duas passagens citadas acima há a aparência de uma mera perífrase do problema. A questão a ser respondida ainda permanece sendo a seguinte: o que seria o estatuto "a priori não puro" do conceito de matéria, ou em que consistiria a "passagem" entre os níveis de pureza da Metafísica da Natureza?

A tarefa inicial dos PPMCN com seu objeto preciso da metafísica da substância corporal consiste em diferenciar o conceito empírico de matéria de duas outras definições fornecidas na Crítica da Razão Pura para o conceito "geral" de matéria. Na primeira delas, dada na "Estética Transcendental", a matéria é definida como o mero material de uma sensação em oposição à forma da mesma ensejada pelas intuições puras de espaço e tempo:

Àquilo que no fenômeno corresponde à sensação eu denomino a matéria do mesmo, mas àquilo que faz com que o diverso do fenômeno possa ser ordenado em determinadas relações eu denomino a sua forma. Como aquilo que permite ordenar e colocar as sensações sob uma determinada forma não pode, por seu turno, ser também uma sensação, a matéria de todos os fenômenos, com efeito, nos é dada então a posteriori, mas a forma dos mesmos tem de estar a priori já pronta para eles no ânimo (Gemüt) e, portanto, tem de poder ser considerada separadamente de toda sensação (KrV A 20 / B 34).

Ora, em oposição ao simples e "estático" material de uma sensação, dado no espaço e/ou no tempo, o conceito empírico de matéria pressupóe uma substância corporal efetivamente dada e que afeta os sentidos através de seu predicado de movimento (Bewegung) ${ }^{17}$. Somente através deste último podemos conhecer verdadeiramente o conceito de matéria de que tratam os $P P M C N$ :

A determinação fundamental de algo que deve ser um objeto dos sentidos externos [a matéria] precisaria ser o movimento, pois só por ele esses sentidos [externos] podem ser afetados. É a ele também que o entendimento remete todos os demais predicados da matéria que pertencem à sua natureza (MAN AA 04: 476-477). 
Nesse sentido, cumpre então distinguir o movimento como predicado nuclear da matéria relativamente à definição dada na dedução transcendental da segunda edição da Crítica da Razão Pura sobre uma aparente "matéria pura" como a mera descrição, pela imaginação produtiva, de um diverso "real” em movimento no espaço:

\begin{abstract}
O movimento de um objeto (Object) no espaço não pertence a uma ciência pura, portanto não também à geometria, pois não se pode conhecer a priori que algo esteja em movimento, mas apenas por meio da experiência. $\mathrm{O}$ movimento como descrição do espaço, porém, é um ato puro da síntese sucessiva do diverso em uma intuição externa em geral por meio da imaginação produtiva e, portanto, não pertence apenas à geometria, mas também à filosofia transcendental ( $\mathrm{KrV}$ B 155n; grifos nossos).
\end{abstract}

Ao passo que a segunda parte da passagem se refere ao ato do sujeito que traça uma linha reta na intuição pura do espaço, e, assim, representa o movimento "não como uma determinação de um objeto" (KrV B 155; grifo nosso) no espaço, mas apenas como uma determinada síntese (sucessiva) do diverso da intuição no espaço, a primeira parte menciona a percepção mesma de um objeto em movimento e que, assim, pertence não à filosofia transcendental stricto sensu, mas antes à metafísica da substância corporal ou ciência da matéria como submetida às leis do movimento. A primeira questão que se põe a respeito da passagem entre esses dois modelos de movimento ou matéria, portanto, gira em torno de saber em que consiste a peculiaridade empírica da metafísica da substância corporal em relação à parte transcendental, ou ainda, o que seria precisamente essa matéria movente no espaço e seu conteúdo empírico.

Já n'“A Arquitetônica da Razão Pura” Kant mostra-se consciente do aparente paradoxo ínsito à tarefa sistemática de mediação ou passagem no interior de seu projeto crítico. Discutindo o caso específico de uma Metafísica da Natureza, ele realça o problema de fundo de uma metafísica aplicada ao mesmo tempo em que propõe uma inicial definição do conceito empírico de matéria:

Como posso esperar um conhecimento a priori, portanto uma metafísica, de objetos na medida em que são dados aos nossos sentidos, e portanto, a posteriori? (...). A resposta é simples: da experiência nada mais tiramos do que o necessário para nos darmos um objeto do sentido (...) externo (...). O objeto do sentido externo nos é dado pelo mero conceito de matéria (extensão inanimada e impenetrável) (KrV A 847-7 / B 875-6; grifo nosso) $)^{18}$.

Bem entendido, a matéria não é tão-somente o objeto dado ao sentido externo. Caso permanecêssemos aqui, nada a distinguiria da pura e simples matéria da sensação externa como o diverso empírico dado no espaço:

Quando tenho de esclarecer o conceito de matéria não através de um predicado que deve pertencerlhe como objeto, mas antes apenas através da relação com as faculdades de conhecimento na qual a representação pode ser-me primeiramente dada, a matéria seria então todo objeto dos sentidos externos, e esta seria a explicação meramente metafísica da mesma (...). A matéria seria o genuinamente empírico das intuições externas e sensíveis, em oposição à forma do que é objeto da sensação na intuição externa (MAN AA 04: 481).

Como está apenas sugerido na "Arquitetônica", cumpre localizar propriedades adicionais para caracterizar o conceito de matéria exigido em uma metafísica da substância corpórea e assim distingui-lo da mera "explicação metafísica" - nesta última, presume-se, entra apenas o conceito puro, e não empírico de matéria. Segundo a passagem da "Arquitetônica" citada acima, em adição ao atributo de ser um objeto do sentido externo, a matéria possui também como propriedades fundamentais, além da extensão, também 
impenetrabilidade e a ausência de força vital (Leblosigkeit); destas dependeria não apenas a sua determinação como "objeto do sentido externo", mas também seu predicado de movente que afeta os sentidos externos, diferenciando-a assim de um simples material da sensação ou do diverso empírico dado no espaço e sintetizado como sucessivo no tempo. São, em suma, esses predicados que inicialmente caracterizam a matéria como movente no espaço de que tratam os PPMCN. Contudo, a partir de quais particularidades destes atributos se funda a definição precisa do elemento empírico mínimo desse conceito de matéria?

O predicado de impenetrabilidade pode auxiliar-nos nesta tarefa ${ }^{19}$. Segundo Kant, haveria dois conceitos concorrentes de impenetrabilidade: por um lado, um conceito meramente matemático, ou seja, "que não pressupõe nenhuma força movente como originariamente inerente à matéria", e, por outro, o conceito dinâmico de impenetrabilidade, segundo o qual esta última "reside numa base física (physischer Grund); pois expandir a força é o que primeiro torna a matéria mesma possível, como algo expansível preenchendo um espaço" (MAN AA 04: 502; grifo nosso). Para a metafísica da substância corpórea deve ser aceito apenas este segundo conceito de impenetrabilidade como predicado da matéria, já que "tudo o que é real no espaço e, não obstante, não é uma mera determinação do espaço (lugar, extensão e figura), deve ser visto como uma força movente" (MAN AA 04: 523; grifos nossos).

Ora, aparentemente o conceito matemático de impenetrabilidade convém apenas ao "mero real no espaço", tratado nas "Antecipações da Percepção" da Crítica da Razão Pura e ao qual cabem os predicados de extensão e preenchimento como as "meras determinações" de um espaço qualquer (lugar, extensão e figura) pertencentes a um puro e simples "objeto do sentido externo"20. Algo "matematicamente impenetrável" não é ainda, no entanto, "fisicamente impenetrável": aquele predicado parece convir somente a um "objeto do sentido externo", mas não a este considerado enquanto um corpo que se move no espaço e afeta os sentidos externos. Com efeito, o mero objeto do sentido externo distingue-se da matéria, pois esta é o "movente, na medida em que este preenche um espaço" (MAN AA 04: 496), o que, por sua vez, ocorre não "através de sua mera existência [da matéria], mas antes através de uma força movente particular" (MAN AA 04: 497; grifo nosso), possível, como visto acima, apenas segundo o conceito dinâmico de impenetrabilidade. Esta força movente é, na realidade, dupla: a atração e a repulsão (MAN AA 04: 498), as quais devem pressupor a impenetrabilidade da matéria como residindo "numa base física", e não em um ponto matemático qualquer ou em algo meramente real no espaço. Esse conceito dinâmico de impenetrabilidade, como se vê, é empírico, pressupondo um elemento sensível mínimo, uma "base física", para diferenciá-lo da impenetrabilidade matemática envolvida no mero real dado no espaço e construída na intuição pura.

A noção de força movente ${ }^{21} \mathrm{e}$ a correlata de impenetrabilidade dinâmica definem, assim, o conceito empírico (dinâmico e não atomístico) de matéria ${ }^{22}$. Segundo Kant, a possibilidade do conceito dinâmico de impenetrabilidade não pode ser explicada a priori, pois a possibilidade de forças fundamentais, dentre elas a força movente, não pode ser elucidada sem o recurso à experiência. Ao contrário da física estritamente matemática, que se apoia no conceito matemático de impenetrabilidade, a física metafísica proposta por Kant, com a noção constitutiva de força movente, deve recorrer a algo que extrapole a construção a priori de seu conceito na intuição sensível:

O conceito de matéria se reduz a meras forças moventes, e não seria possível esperar algo distinto, pois no espaço não pode ser pensada nenhuma atividade, nenhuma mudança que não seja movimento (...). Se o material (Stoff) mesmo é transformado em forças fundamentais (...), faltam-nos todos os meios para construir esse conceito de matéria e apresentar na intuição o que pensamos universalmente como possível (MAN AA 04: 524-525; grifo nosso). 
Para ser formulado, o conceito empírico de matéria exige, assim, noções que extrapolam a parte estritamente transcendental da Metafísica da Natureza, a saber, as noções de força movente e de impenetrabilidade dinâmica como condições para o movimento. Ao contrário do que ocorre com o conceito puro de matéria como o real da sensação em movimento num determinado intervalo de tempo e que, assim, pode ser construído na intuição com auxílio do instrumental matemático, no conceito empírico de matéria como o movente no espaço que afeta os sentidos há a necessidade de recorrer-se à experiência para que seja possível discernir a presença daqueles predicados empíricos que lhe são constitutivos e que não podem ser simplesmente construídos na intuição. Com efeito, para Kant, conceitos como o de uma força em geral somente podem ter sua realidade objetiva demonstrada pela experiência - e, por conseguinte, os de força de atração e força de repulsão:

Nenhuma lei da força de atração ou de repulsão pode ser negada sob conjecturas a priori; inversamente, tudo, mesmo a atração universal como causa da gravidade, deve ser inferido, conjuntamente com suas leis, a partir de dados (Datis) da experiência. (...). Pois está muito além do horizonte de nossa razão discernir (einsehen) forças fundamentais de modo a priori segundo sua possibilidade (MAN AA 04: 534; grifos nossos).

Ao contrário de outras forças fundamentais, amiúde forjadas a partir de ilações fantasiosas do investigador da natureza ${ }^{23}$, a repulsão e a atração são forças constitutivas do conceito de algo movente no espaço e, enquanto tais, ainda que seja necessário recorrer ao relato da experiência para atestar sua realidade objetiva, são passíveis de uma sistematização segundo princípios a priori - não, decerto, quanto à possibilidade interna dessas forças, mas antes quanto aos "efeitos" das mesmas, ao seu "produto": o movimento da matéria e as leis que o regulam ${ }^{24}$. Isto não significa, bem entendido, que as leis do movimento sejam fundadas empiricamente, ou que o "testemunho" da experiência seja necessário para fundá-las pelo contrário, como se tornará mais claro na seção seguinte, trata-se de princípios metafísicos e de leis, por assim dizer, a priori não puras.

Definido o elemento empírico mínimo do conceito de matéria como a "base física" que permite a impenetrabilidade dinâmica e a atuação das forças moventes de atração e repulsão, Kant pode determinar os seus demais predicados com auxílio do fio condutor das categorias. Deste modo, e aqui apenas reproduzimos os resultados da análise kantiana, num primeiro momento "considera-se o movimento como puro quantum, segundo sua composição, omitindo a qualidade do móvel" (trata-se da "explicação meramente metafísica" da matéria, mencionada acima); num segundo momento, "estuda-o [o movimento] como pertencente à qualidade da matéria, sob o nome de uma força originalmente movente"; num terceiro momento, "considera-se a matéria dotada desta qualidade em relação recíproca devido ao próprio movimento"; no quarto e último momento, "determina-se o seu movimento ou repouso simplesmente em relação com o modo de representação” (MAN AA 04: 477). O conceito empírico de matéria é, assim, determinado completamente de acordo com as únicas formas pelas quais algo "pode afetar os sentidos externos", ou seja, através de sua subsunção, respectivamente, às categorias de quantidade, qualidade, relação e modalidade, ensejando as quatro partes que compõem os PPMCN: foronomia, dinâmica, mecânica e fenomenologia, e instaurando-se, por fim, a completude do sistema metafísico dos corpos externos como uma "teoria do movimento" (ibidem).

Em suma, o conceito de matéria é caracterizado como empírico não apenas porque sua realidade objetiva somente pode ser demonstrada através da experiência ${ }^{25}$, mas também porque seu conteúdo pressupõe uma base física mínima na qual se apoiam seus predicados de impenetrabilidade e de força movente. Não 
obstante, trata-se de características empíricas mínimas que não impedem que as leis que o regulam possam ser determinadas de modo a priori, conforme exige o significado mesmo de uma metafísica aplicada consideram-se tão-somente as leis que o determinam de modo a priori como movente, ou seja, como o dado mínimo exigido para que algo afete os sentidos externos. Ocorre aqui a aplicação dos princípios transcendentais a esse conceito empírico de matéria, uma aplicação, cumpre sublinhar, "intrametafísica", ou seja, que não depende de elementos empíricos adicionais àqueles pressupostos por aquele conceito. Voltemo-nos agora mais detidamente ao sentido dessas "leis metafísicas" envolvidas aqui.

\section{PRINCÍPIOS TRANSCENDENTAIS E PRINCÍPIOS METAFÍSICOS.}

Como visto acima, os PPMCN têm como objetivo arrolar as leis que determinam o conceito empírico de matéria como o movente no espaço que afeta os sentidos externos. No interior desse projeto, os princípios transcendentais, que se limitam a constituir um objeto em geral dos sentidos externos ou do sentido interno, devem ser especificados como princípios que estipulam as leis que regulam a matéria enquanto leis do movimento. Trata-se, assim, de ultrapassar o formalismo da etapa transcendental e "concretizar" seus conceitos e princípios no molde empírico, porém determinável a priori, exigido por uma metafísica aplicada a um âmbito específico da experiência. Temos, aqui, a distinção entre princípio transcendental e princípio metafísico, discutida na Introdução à Crítica da Faculdade de Julgar:

Um princípio transcendental é aquele pelo qual é representada a priori a condição universal unicamente sob a qual as coisas podem ser objetos do nosso conhecimento em geral. Em contrapartida, um princípio chama-se metafísico, se representa a priori a condição unicamente sob a qual objetos, cujo conceito tem que ser dado empiricamente, podem ser ainda determinados a priori (KU AA 05: 181; grifos nossos) ${ }^{26}$.

Há a reprodução da diferença que opunha a parte transcendental da parte metafísica específica de uma Metafísica da Natureza. Ao passo que um princípio transcendental é caracterizado como aquele que estipula as condições sob as quais um objeto qualquer é inicialmente determinado como um objeto da experiência em geral, ou seja, como um objeto do "nosso conhecimento em geral", um princípio metafísico deve ser aquele que representa de modo a priori as condições sob as quais um objeto específico da experiência, ou seja, que tem de ser dado empiricamente e, assim, não se limita à pura e simples condição de ser um objeto em geral da experiência, pode, não obstante, ser determinado de modo a priori e, portanto, necessário e universal - em nosso caso, a maneira pela qual pode ser determinada de modo a priori a matéria, cujo "conceito tem de ser dado empiricamente" através dos predicados de impenetrabilidade dinâmica e força movente.

Na Crítica da Razão Pura, mais precisamente na discussão empreendida n'“A Disciplina da Razão Pura no Uso Dogmático" contra a aplicação do método matemático em filosofia, Kant escreve que proposições transcendentais

não se podem nunca dar por construção de conceitos [como no caso da matemática - D. K. T.], mas apenas segundo conceitos a priori. Elas contêm simplesmente a regra segundo a qual uma certa unidade sintética daquilo que não pode ser representado intuitivamente a priori (das percepções) deve ser procurado empiricamente. Mas não podem, em caso algum, apresentar a priori nenhum dos seus conceitos, apenas o fazem a posteriori, mediante a experiência, que só se torna possível de acordo com essas proposições sintéticas (KrV A 720-721 / B 748-749). 
Um princípio transcendental, assim, é apenas a regra que preside a síntese a priori de um diverso empírico dado à sensibilidade e que, dessa maneira, constitui um objeto qualquer da experiência. Bem entendido, esse diverso somente pode ser dado através de uma percepção empírica, ou seja, a matéria da percepção, que pode ser conhecida apenas de modo a posteriori. Contudo, isso significa que o princípio transcendental aqui descrito assemelha-se ao princípio metafísico discutido na Crítica da Faculdade de Julgar? De forma alguma. Nessa passagem da Crítica da Razão Pura, Kant está apenas retomando a limitação imposta à "ontologia" crítica, a saber, que através de uma proposição transcendental temos as condições a priori que constituem um "objeto em geral", o qual é somente um "objeto da experiência geral” e cujo conteúdo, enquanto tal, é dado de modo a posteriori:

A matéria dos fenômenos (...), pela qual nos são dadas coisas no espaço e no tempo, pode apenas ser representada na percepção e, por conseguinte, a posteriori. O único conceito que representa a priori este conteúdo empírico dos fenômenos é o conceito de coisa em geral e o conhecimento sintético a priori desse conceito não pode fornecer mais do que a simples regra da síntese daquilo que pode dar a percepção a posteriori, mas nunca fornecer a intuição do objeto real, porque esta deve ser necessariamente empírica ( $\mathrm{KrV}$ A 720 / B 748; grifos nossos).

Como se vê, o conceito tomado como base da regra de síntese estipulada pelo princípio transcendental é o conceito de coisa ou objeto em geral, entendido como o conceito de objeto de uma experiência em geral e que, enquanto tal, representa, de modo a priori e necessário, os limites no interior dos quais a matéria dos fenômenos pode ser sintetizada em um objeto (empírico) da percepção em geral. Nessa medida, o conceito de coisa em geral é dado a priori, muito embora a determinação do conteúdo determinado do mesmo precise da matéria da sensação, a qual, por seu turno, somente é dada a posteriori. Trata-se aqui apenas do conceito que apresenta, de modo a priori, a regra da síntese de representações que somente podem ser dadas a posteriori, no espaço e no tempo ${ }^{27}$. Pelo contrário, em um princípio metafísico é o conceito mesmo do objeto que precisa ser dado de modo a posteriori, ou seja, através de um recurso "mínimo" à experiência - trata-se, como visto, do conceito empírico de matéria, que, não obstante, pode ser determinado de modo a priori em suas determinações fundamentais como movente através de princípios metafísicos.

Na sequência do trecho da Crítica da Faculdade de Julgar citado, o argumento aqui avançado é confirmado. Como exemplo de um princípio transcendental, Kant fornece o "princípio de conhecimento dos corpos como substância e como substâncias suscetíveis de mudança (Veränderung)", e como exemplo de um princípio metafísico, o princípio da mudança "se com isso se significar que a sua mudança tem que ter uma causa externa”, ou seja, se deve (de acordo, portanto, com a lei de inércia, como se verá) ser movimento (Bewegung). Segundo Kant,

[a] razão é que, no primeiro caso [princípios transcendentais], para se conhecer a proposição a priori, o corpo só pode ser pensado mediante predicados ontológicos (conceitos do entendimento puro), por exemplo como substância; porém, no segundo [princípios metafísicos], o conceito empírico de um corpo (como de uma coisa que se move no espaço) tem que ser colocado como princípio dessa proposição, embora então possa ser compreendido completamente a priori (völlig a priori eingesehen) que o último predicado (do movimento somente mediante causas externas) convém ao corpo (KU AA 05: 181; grifos nossos).

Ora, o conceito de "substância" assumido pelo princípio transcendental de mudança é um conceito "completamente a priori", pressuposto para que um objeto qualquer, seja ele dos sentidos externo ou do sentido interno, possa ser tomado como objeto de uma experiência possível - trata-se, aqui, da determinação categorial da substância como o substrato que permanece em toda sucessão temporal de determinações opostas: 
tem de ser encontrado nos objetos da percepção, isto é, nos fenômenos, o substrato que representa o tempo em geral, e no qual toda modificação (Wechsel) ou simultaneidade pode ser percebida na apreensão por meio da relação dos fenômenos a ele. O substrato de todo real, contudo, isto é, aquilo que pertence à existência das coisas, é a substância, em que tudo que pertence à existência só pode ser pensado como determinação. O único permanente, portanto, em relação ao qual todas as relações temporais dos fenômenos podem ser determinadas, é a substância no fenômeno, isto é, o real do mesmo que, como substrato de toda modificação, permanece sempre o mesmo (KrV B 225; grifos nossos).

Há a presença apenas do "real do fenômeno" tomado como substância em relações dinâmicas, ou seja, aquilo que, como vimos, apenas preenche um espaço e permanece como substrato das mudanças na sucessão temporal das determinações que lhe são seguidamente atribuídas. Contudo, para que essa substância seja caracterizada como um movente cuja causa da mudança é externa, é necessário ainda considerá-la como uma substância corporal, o que ocorre, como dito, na passagem da Crítica da Faculdade de Julgar, caso o "conceito empírico de um corpo" seja colocado como "princípio da proposição", o que, por seu turno, somente tem lugar na segunda lei da mecânica, a lei de inércia, em oposição à segunda analogia da experiência, o princípio de causalidade:

Segunda lei da mecânica. Toda mudança da matéria tem uma causa externa. (Todo corpo persiste num estado de repouso ou movimento, na mesma direção e com a mesma velocidade, se não for compelido por uma causa externa para deixar esse estado) (MAN AA 04: 543; segundo grifo nosso).

Segunda analogia [da experiência]. - Princípio da sucessão temporal segundo a lei da causalidade. Todas as mudanças acontecem segundo a lei da conexão de causa e efeito (KrV B 232).

O paralelo é confirmado por Kant na "prova” à segunda lei da mecânica:

Da metafísica geral nós tomamos como base a proposição de que cada mudança tem uma causa, e aqui $[P P M C N]$ somente deve ser provado da matéria que sua mudança precisa sempre possuir uma causa externa (MAN AA 04: 543; grifo nosso).

Passando-se por cima dos detalhes, que aqui não nos interessam, torna-se claro que o objetivo de Kant com esse argumento é indicar como os PPMCN, cuja função é determinar de forma a priori o "conceito empírico" de matéria, devem lançar mão de princípios metafísicos no sentido descrito na introdução à Crítica da Faculdade de Julgar, em oposição aos princípios transcendentais presentes na Crítica da Razão Pura, mais precisamente na "Analítica dos Princípios". No caso específico da lei da inércia, trata-se de tomar como a "substância" que muda não apenas algum real da intuição externa, mas, antes, a matéria com seus predicados empíricos de impenetrabilidade dinâmica e de força movente, unicamente através dos quais é posta em movimento pelos outros corpos e pode, ela mesma, afetá-los e movimentá-los.

Como resultado, tem-se uma correspondência entre, por um lado, cada uma das categorias e seus princípios transcendentais correlatos e, por outro, os princípios metafísicos que regulam o comportamento da matéria como movente no espaço: à categoria de inerência ou substância e ao princípio de permanência da substância ( $\mathrm{KrV}$ B 224) corresponde o princípio de constância da quantidade da matéria ou primeira lei da mecânica (MAN AA 04: 541); à categoria de causalidade ou dependência e ao princípio de causalidade ( $\mathrm{KrV}$ B 232), como já discutido, o princípio de inércia ou segunda lei da mecânica (MAN AA 04: 543); à categoria de comunidade e ao princípio de ação recíproca das substâncias (KrV B 256), o princípio de igualdade de ação e de reação, ou terceira lei da mecânica (MAN AA 04: 544)28. 
Dessa maneira, as leis (newtonianas) do movimento, que compõem a metafísica da substância corporal e determinam de forma a priori o conceito empírico de matéria como movente, são todas "princípios metafísicos", que "representam a priori a condição unicamente sob a qual objetos, cujo conceito tem que ser dado empiricamente, podem ser ainda determinados a priori", a saber, a matéria como o conceito empírico de um movente no espaço.

O caráter ambíguo da ciência metafísica "pura" da natureza, aludido no início da seção, é dissolvido quando se atenta à peculiaridade do conceito de matéria como movente no espaço e dos princípios metafísicos que a determinam. Com efeito, a posição da matéria é central para a definição precisa do caráter a priori não puro de Metafísica da Natureza. Como deixam bem claro os Prolegômenos, a ciência pura da natureza, por necessitar do conceito empírico de matéria, não seria, na verdade, uma ciência "absolutamente pura" (ganz reine) da natureza, mas antes, se assim se deseja, uma ciência a priori não pura do objeto do sentido externo. Vale a pena citar a longa passagem dos Prolegômenos onde Kant torna explícito o caráter não "absolutamente puro" da Metafísica da Natureza.

\footnotetext{
Ora, estamos realmente na posse de uma ciência pura da natureza, que apresenta a priori e com toda aquela necessidade que se exige das proposições apodíticas, leis a que a natureza se encontra submetida. Permitome aqui apelar apenas ao testemunho dessa propedêutica da teoria da natureza que, sob o título geral de ciência universal da natureza, precede toda a física (que se funda em princípios empíricos). Encontra-se aí a matemática aplicada a fenômenos, e também princípios puramente discursivos (por conceitos), que constituem a parte filosófica do conhecimento puro da natureza. Mas encontram-se aí também muitas coisas que não são absolutamente puras (ganz rein) e independentes das fontes da experiência: como o conceito de movimento, de impenetrabilidade (onde se funda o conceito empírico de matéria), de inércia, etc., que impedem chamá-la uma ciência absolutamente pura (ganz reine) da natureza; além disso, ela refere-se apenas a objetos dos sentidos externos e, por conseguinte, não fornece nenhum exemplo de uma ciência universal da natureza em sentido forte, porque deve conduzir sob leis universais a natureza em geral, quer se trate do objeto dos sentidos externos ou do [objeto] do sentido interno (do objeto da física e do da psicologia). Mas, entre os princípios dessa física universal, há alguns que possuem realmente a universalidade que exigimos, como a proposição: que a substância permanece e persiste (bleibt und beharrt), que tudo o que acontece é sempre determinado previamente por uma causa segundo leis constantes, etc. Estas são verdadeiramente leis universais, que existem absolutamente a priori. Existe, pois, de fato, uma ciência pura da natureza (Prol AA 04: 294-295; grifo nossos).
}

Kant admite que a ciência "pura" da natureza, mais especificamente a metafísica da substância corporal, não é, na realidade, uma ciência "absolutamente pura”, já que contém conceitos (movimento, impenetrabilidade, etc.), que dependem "das fontes da experiência" (Erfahrungsquellen); por outro lado, há certas "leis absolutamente a priori", como o princípio da permanência da substância e o princípio da causalidade. A Metafísica da Natureza, assim, por possuir em seu interior essas duas partes implicitamente mencionadas na passagem dos Prolegômenos, a transcendental e a metafísico-específica, poderia ser considerada, em oposição à física empírica, como uma ciência a priori não pura, ou ainda, que não é "absolutamente pura".

\section{A “REALIZAÇÃO” DOS PRINCÍPIOS TRANSCENDENTAIS E NECESSIDADE DE UMA PASSAGEM PARA O EMPÍRICO.}

Estamos agora em condições de compreender de maneira mais adequada o objetivo de uma Metafísica da Natureza mencionado anteriormente e contido, de forma não explícita, no próprio caráter a priori não puro desta disciplina. No momento em que visam um corpo que se move no espaço, os princípios 
transcendentais, tornados "metafísicos" ao assumirem por base o conceito empírico de matéria, realizamse, ou ainda, ganham "sentido e significado". Relembremos o conhecido trecho do prefácio aos PPMCN:

E assim uma metafísica separada da natureza corpórea presta um serviço excelente e indispensável para a metafísica universal, fornecendo-lhe, por meio disso, exemplos (casos in concreto) de como realizar os conceitos e princípios da última (genuinamente a filosofia transcendental), isto é, fornecer significado e sentido (Bedeutung und Sinn) a meras formas de pensamento (MAN AA 04: 478; grifos nossos).

Com efeito, o sucesso que Kant julgava ter obtido em seus PPMCN o fez alterar e acrescentar partes significativas na segunda edição da Crítica da Razão Pura, dentre elas a redação de uma "Observação Geral ao Sistema dos Princípios”, ausente na primeira edição, justamente ao cabo do capítulo em que figuram os "princípios transcendentais" aqui discutidos. Em determinado momento desse acréscimo à segunda edição da primeira Crítica, Kant escreve:

\begin{abstract}
para expor a mudança (Veränderung) como a intuição correspondente ao conceito de causalidade, temos de tomar o movimento (Bewegung) como exemplo de mudança no espaço, que é o único modo, com efeito, de tornar intuíveis as modificações cuja possibilidade nenhum puro entendimento pode compreender ( $\mathrm{KrV} \mathrm{B}$ 291; grifos nossos).
\end{abstract}

A ideia é clara o suficiente: Kant afirma aqui que o princípio de causalidade, que pressupõe o conceito de mudança, somente é tornado "intuível" (anschaulich) através da segunda lei da mecânica, que, por seu turno, pressupõe o conceito de matéria como movente no espaço. Em suma, o princípio de causalidade, cuja possibilidade pode ser discernida de modo completamente a priori, somente ganharia "sentido" e "significado", ou, em outras palavras, se "realizaria", em uma metafísica da substância corporal e seu conceito empírico de matéria. Com efeito, Kant vai mais longe e afirma que a própria realidade objetiva das categorias apenas pode ser demonstrada ou exemplificada quando se toma uma intuição empírica qualquer ou uma matéria como movente no espaço:

Mais curioso ainda, porém, é que, para compreender a possibilidade das coisas como consequência das categorias e, portanto, estabelecer a realidade objetiva das últimas, precisemos não apenas de intuições em geral, mas sempre também de intuições externas ( $\mathrm{KrV}$ B 291).

O papel desempenhado pela metafísica da substância corporal não pode ser, portanto, menosprezado: trata-se da disciplina que, a despeito de todo o esforço de demonstração ou prova da realidade objetiva das categorias como condições de possibilidade da experiência possível despendido nos capítulos sobre a dedução transcendental e o esquematismo da Crítica da Razão Pura, torna concreta a abstração dos princípios e conceitos da "Analítica Transcendental" - em outras palavras, realiza a parte transcendental da Metafísica da Natureza ou ontologia ao conceder-lhe significado concreto e um referente determinado na experiência ${ }^{29}$.

SegundoJules Vuillemin, haveria aquiuma marca central do que ele denomina um movimentofenomenológico presente na filosofia teórica kantiana ${ }^{30}$. Para o comentador, apenas em uma metafísica da substância corporal a "verdade" das etapas transcendentais anteriores seria definitivamente demonstrada, em virtude justamente do processo de realização dos conceitos e proposições transcendentais impulsionado pela sua instanciação em um elemento empírico contido no movimento da matéria que afeta os sentidos externos; - ainda de acordo com Vuillemin, tratar-se-ia de um "travo" (Ansto $\beta$ ) de que dependem sub-repticiamente a realidade objetiva e a "verdade" de todo o arcabouço transcendental erigido na Crítica da Razão Pura. 
O procedimento, descrito nesse artigo, de uma formação gradativa de um objeto do sentido externo como uma matéria movente evidenciaria o movimento fenomenológico exigido para se chegar à evidência dos princípios transcendentais. O método kantiano pressuporia um "fio condutor" que perpassa a análise da experiência: ao distinguir intuição e conceito no interior de seu sistema, Kant postula uma "constituição progressiva" que faz a passagem da "síntese matemática" à "síntese física"; trata-se da "constituição progressiva do esquematismo", ou seja,

\footnotetext{
das mediações necessárias para fazer corresponder uma intuição ao conceito que a determina, a exposição dos atos pelos quais o pensamento coloca de maneira a priori, ainda que impura, e pelo procedimento do mínimo tomado de empréstimo à experiência, os diferentes 'dados' que lhe são necessários, a constatação, enfim, de que o progresso do esquematismo e a aproximação do objeto físico determinado obrigam a reflexão a abandonar gradualmente a esperança de uma evidência imediata, tal como aquela com a qual sonhava a filosofia de Descartes (VUILLEMIN, 1955, p. 25).
}

De acordo com Vuillemin, o abandono de uma física cartesiana e mesmo o "rebaixamento" da matemática em relação à física de Newton (e a boa parte da tradição racionalista, ressalte-se) fazem com que para Kant a evidência exigida e procurada somente ocorra de maneira indireta, por meio do distendido e progressivo desenrolar dos níveis de pureza da Metafísica da Natureza: os conceitos do entendimento se "realizariam" no esquematismo, este, por sua vez, no sistema dos princípios, e estes, por fim, nos princípios metafísicos dos PPMCN. Uma "fenomenologia" de molde hegeliano instala-se, assim, no cerne do sistema transcendental:

\begin{abstract}
Apenas no momento em que a filosofia transcendental, como sistema dos atos constituintes do entendimento puro, coloca seu objeto concreto na fisiologia racional [ou metafísica da substância corporal], referindo-se ao dado mínimo da sensação, é que essa posição esclarece suas próprias premissas e obriga o sujeito transcendental a recorrer a um outro princípio, que engloba o primeiro e lhe confere sua 'verdade' (VUILLEMIN, 1955, p. 39).
\end{abstract}

A despeito das claras marcas de um "cientificismo" ou "epistemologismo"31 que aproxima sua análise daquela empreendida pelos neokantianos e, assim, a nossos olhos, a empobrece com vistas ao intuito mais amplo de compreensão dos objetivos de fundo da filosofia crítica ${ }^{32}$, bem como resguardadas as diversas questões que essa espécie de interpretação levanta quanto à sua adequação à "letra" kantiana, a leitura de Vuillemin desperta interesse por ressaltar a necessidade de uma metafísica aplicada como a disciplina na qual ocorre a efetivação dos enunciados transcendentais e na qual, com efeito, ganha-se a concretude que falta ao tão acusado "formalismo" kantiano. A "verdade" de um princípio transcendental deduzido precisaria a fortiori esperar a sua realização na experiência, a sua instanciação em algum dado que extrapola a abstração - "demonstrada transcendentalmente", é bem verdade - da parte "propedêutica” da filosofia da natureza.

Seria, pois, essa necessidade de uma referência constante a um elemento "concreto" que possa realizar os princípios formais e abstratos da filosofia transcendental, aquilo que levou Kant, já no final de sua vida, a sentir a urgência de uma obra adicional e "final" que pudesse realizar a passagem "definitiva" dos princípios a priori da metafísica da natureza para os princípios da física empírica e, com isso, levar a cabo as pretensões de completude de seu sistema? Em carta a Garve, de 21.09.1798, Kant é bem claro sobre a importância da obra na qual vinha se debruçando havia ao menos 2 anos e meio: tal obra projetada, a "Passagem dos Primeiros Princípios Metafísicos da Ciência da Natureza para a Física", tinha de ser concretizada, "pois, do contrário, haveria uma lacuna no sistema da filosofia crítica. As pretensões da 
razão não se arrefecerão, assim como a consciência da capacidade para tanto; contudo, a sua satisfação será continuamente protelada até a mais alta impaciência, quando não pela completa paralisia das minhas forças vitais, ao menos pela sua crescente limitação" (AA 12: 257). Esse "suplício de Tântalo", que na mesma carta Kant dizia enfrentar, não foi de fato levado a cabo. O testemunho dos incessantes e penosos esforços de Kant em construir a última ponte entre o âmbito transcendental e o empírico é hoje encontrado no Opus Postumum. A obra colmata o "problema, que perpassa toda a obra de Kant, da ligação entre conteúdos materiais desenvolvidos sistematicamente de modo não raro dicotômico" ${ }^{\text {"33 }}$, examinando não apenas o tema da passagem da doutrina metafísica da natureza para a física empírica, como também apresentando reflexões sobre o acabamento sistemático da filosofia transcendental. Não é sem ironia que os primeiros grandes sistemas pós-kantianos como os de Schelling e de Fichte, impulsionados pelo que reputavam ser as insuficiências e lacunas sistemáticas do inaugurador da filosofia crítica, começavam a ganhar forma simultaneamente à redação da última grande obra do velho mestre, da qual, de resto, seus "seguidores" imediatos não tinham e não tiveram notícia. Analisar as curiosas similaridades entre certos elementos centrais do idealismo alemão e algumas das doutrinas expostas de modo vacilante e quase cifrado no Opus Postumum, como a Selbstsetzungslehre, seria um desiderato não desprezível, o qual, contudo, não temos aqui condições de realizar.

\section{NOTAS}

1. Este trabalho contou com o apoio da FAPESP e do DAAD.

2. Até hoje o estudo mais completo e exaustivo sobre Kant como "cientista ou filósofo da natureza" encontra-se na obra clássica de Erich Adickes, Kant als Naturforscher, publicada em dois tomos em 1924 (ADICKES, 1924). Adickes percorre toda a produção filosófica de Kant e discute, temática e cronologicamente, os temas científicos nela tratados, a relação da filosofia crítica e pré-crítica com a ciência de seu tempo e os precedentes históricos das doutrinas abordadas. Nessa mesma chave histórica, vale destacar também os estudos de Cassirer (1999) e de Vuillemin (1955). Infelizmente não abordaremos aqui a concepção précrítica de matéria, movimento, força e, de modo geral, ciência da natureza e tampouco a gênese histórica da filosofia natural de Kant. Para tanto, consultar os autores aqui mencionados.

3. Na Ciência da Lógica, Hegel complementa: os PPMCN "deram o impulso para uma nova filosofia da natureza - a filosofia que não faz da natureza um fundamento da ciência enquanto um dado sensível da percepção, mas, antes, conhece suas determinações a partir do conceito absoluto" (HEGEL, 2000, p. 286).

\section{SCHELLING, 1994.}

5. HEGEL, 2000, p. 285-296; 2001, p. 96-101.

6. Dito de modo quase que caricatural, o movimento neokantiano representado por, dentre muitos outros, Cassirer, Natorp, Rickert, Cohen e, de modo oblíquo, Adickes, pretendia bater-se contra o idealismo exacerbado e "anticientífico" dos neohegelianos e para tanto identificava na Crítica da Razão Pura essencialmente uma obra de fundamentação filosófica da física newtoniana: o "procedimento crítico-transcendental" consistiria em partir de um factum da ciência e, deduzindo post festum suas condições de possibilidade, conceder-lhe justificação filosófica (Para um amplo panorama do movimento, cf. KÖHNKE, 1993). A exemplo do que ocorria com a filosofia moral kantiana, interpretada por Cohen como tendo "perdido a aplicação do método transcendental" na medida em que não identificava uma ciência prática positiva da qual pudesse fornecer a base filosófica (cf. COHEN, 1907, p. 227), também os PPCMN são taxados como uma instância malfadada de aplicação do método transcendental da Crítica da Razão Pura. "Se se permanece firmemente no ponto de vista da Crítica da Razão Pura, não existe possibilidade alguma de obterse o conteúdo dos PPMCN pela aplicação do método transcendental” (ADICKES, 1924, p. 370).

7. Dentre as obras que se esforçam em reconstituir a sistemática interna e externa dos PPMCN, destacam-se FRIEDMAN, 2001; PLAASS, 1965; e VUILLEMIN, 1955.

8. Cf. por exemplo, WOLFF, 2006, \$\$ 56-73; 1962. 
9. As obras de Kant são citadas segundo a edição da Academia (Kants gesammelte Schriften. Herausgegeben von der Deutschen Akademie der Wissenschaften, anteriormente Königliche Preussischen Akademie der Wissenschaften. Berlin: Walter de Gruyter, 1900-, 29 vols.) e de acordo com o seguinte modelo: GMS AA 04: 388, ou seja, a abreviatura do nome da obra seguida do volume e da página da edição da Academia. Nas citações da Crítica da Razão Pura, a página da edição da Academia é substituída pelas mais convencionais referências "A" e "B", correspondentes à primeira e à segunda edições da obra, respectivamente. Na bibliografia encontram-se as traduções para o português consultadas e eventualmente modificadas por nós. Foram utilizadas as seguintes abreviaturas: FM (Progressos da Metafísica), KrV (Crítica da Razão Pura), KU (Crítica da Faculdade de Julgar), MS (Metafísica dos Costumes), MAN (Primeiros Princípios Metafísicos da Ciência da Natureza), Prol (Prolegômenos a Toda Metafísica Futura), V-Met/Dohna (Lições de Metafísica Dohna), V-Met/Mron (Lições de Metafísica Mrongovius).

10. A concepção de natureza assumida nos PPMCN é a conjunção dos significados formaliter e materialiter do conceito formal de natureza (Formale der Natur) exposto com detalhes nos Prolegômenos, ou seja, o conjunto de objetos da experiência determinados de modo a priori segundo sua conformidade a leis universais e constantes: "A natureza [formaliter] é a existência das coisas [tomadas como fenômenos] enquanto esta é determinada segundo leis universais" (Prol AA 04: 294). No entanto, "a palavra natureza assume ainda outro significado, que determina o objeto, ao passo que na significação precedente ela indicava a conformidade a leis das determinações da existência das coisas em geral. Portanto, materialiter considerada, a natureza é a totalidade de todos os objetos da experiência" (Prol AA 04: 295). Como resultado, portanto, "o elemento formal [formaliter e materialiter] da natureza, nesse sentido estrito, é a conformidade a leis de todos os objetos da experiência e, enquanto é conhecida a priori, a sua conformidade necessária a leis" (Prol AA 04: 196. Cf. ainda MAN AA 04: 467; KrV B 163). Perceba-se que, operando com uma concepção de natureza como o conjunto dos objetos da experiência, Kant se afasta ligeiramente da concepção exposta n'”A Arquitetônica da Razão Pura", segundo a qual a Metafísica da Natureza acolheria, ao menos potencialmente, objetos imanentes e transcendentes - objetos "sejam dados aos sentidos, sejam dados, se se quiser, a uma outra espécie de intuição" (KrV A 845 / B 873). Quem chama atenção para isso é Hoppe, que acertadamente afirma que Kant, na "Arquitetônica", está lidando com a "ideia geral de metafísica" (KrV A 850/ B 878), a qual inclui necessariamente um saber não apenas verdadeiro, como o da física racional, mas também aparente, como o das disciplinas da metaphysica specialis exigidas pela "ideia" dessa ciência. Contudo, Hoppe conclui disso que a "ontologia" da "Arquitetônica" não corresponde à parte transcendental dos PPMCN (HOPPE, 1969, p. 33-34), com o que, no entanto, não concordamos. Contra Hoppe, cf. CRAMER, 1985, p. 121n.

11. Segundo Konrad Cramer, Kant aqui se afasta de Newton, para quem a primeira e "genuína" parte da ciência da natureza não seria uma metafísica, mas antes uma "matemática da natureza" (CRAMER, 1989, p. 119n). Como já mencionado, para Kant, a matemática entra apenas no segundo momento da ciência pura ou metafísica da natureza - trata-se de um expediente posterior, embora imprescindível, para a aplicação dos princípios transcendentais ao conceito empírico de matéria e/ou de alma (MAN AA 04: 470-471).

12. "[A] primeira [filosofia transcendental] considera apenas o entendimento e a própria razão num sistema de todos os conceitos e princípios que se referem a objetos em geral sem admitir objetos que sejam dados (ontologia); a segunda [fisiologia racional] considera a natureza, isto é, o conjunto dos objetos dados (sejam dados aos sentidos, sejam dados, se se quiser, a uma outra espécie de intuição), e é portanto uma fisiologia (KrV A 845/ B 873). Já analisamos em outro lugar as divisões da metafísica no capítulo da "Arquitetônica" e, de modo geral, o conceito kantiano de metafísica. Cf. TREVISAN, 2014.

13. Segundo K. Cramer, o pressuposto da parte transcendental é apenas o "ser-dado" (Gegebenheit) de algum diverso na intuição capaz de ser sintetizado pelas categorias em algum objeto da experiência em geral: "De fato, também a parte transcendental precisa referir-se ao ser-dado, de modo que a ela, como parte transcendental, possa ser previamente dado (vorgeben) apenas aquele diverso de certas representações que Kant, com suas formas apriorísticas da sensibilidade, denomina o 'diverso puro dado' da sensibilidade" (CRAMER, 1989, p. 123). Não se trata, neste momento preciso, de considerar esse diverso como dado no espaço e/ou no tempo, mas antes apenas em algum dos dois, conforme é exigido para a constituição da objetividade do conhecimento.

14. Cf. MAN AA 04: 471; KrV A 381ss.; cf. CAIMI, 1989, p. 104. Segundo Kant, como não é possível aplicar a matemática aos fenômenos do sentido interno, tampouco é possível um tratamento sistemático da doutrina da substância pensante e, com isso, não é possível nenhuma metafísica da alma. A matemática é exigida para que o conceito de um objeto natural determinado (seja do sentido externo, seja do sentido interno) possa ser construído na intuição e, assim, seja tomado não mais como meramente possível, mas também como algo que "existe fora do pensamento" (MAN AA 04: 470). Para a aplicação completa do instrumental matemático é necessária, por sua vez, uma "dupla dimensão", a saber, espaço e tempo, o que falta às representações do sentido interno, submetidas apenas ao tempo. Desse modo, da substância pensante apenas é possível dizer que ela está submetida à "lei de continuidade, para o fluir das mudanças interiores", o que na matemática equivaleria tão-somente à "propriedade da linha reta relativamente a toda a geometria". 
15. Para o termo "metafísica aplicada", ver a Lições de Metafísica Mrongovius: "A segunda parte [do sistema da metafísica], a aplicação dos princípios a priori a objetos da experiência, seria a metafísica aplicada (metaphysica applicata)" (V-Met/Mron AA 29: 751). 16. Há aqui apenas o primeiro nível das passagens internas à ciência da natureza. O problema de uma passagem dos $P P M C N$ à física empírica ocupa parte do Opus Postumum de Kant, como veremos na última seção do presente artigo. Cf. AA 21 e 22; cf. ainda TERRA, 2003.

17. Cf. HOPPE, 1969, p. 35-36. Jules Vuillemin chega mesmo a aproximar ao "travo" (Anstoß) dos pós-kantianos a peculiaridade empírica do conceito de matéria, que enseja a "consciência do movimento" e, com isso, afeta os sentidos externos: "É necessário um mínimo de dado, que os pós-kantianos chamarão de travo, para provocar a consciência do movimento e para transformar, naqueles, a intuição intelectual em intuição empírica ou a análise em síntese, e, em Kant, o conceito do Eu penso em princípios da experiência" (VUILLEMIN, 1955, p. 24). Mais sobre isso adiante.

\section{Cf. também KrV A 618 / B 646.}

\section{Cf. FRIEDMAN, 2001, p. 332-334.}

20. “[O] real no espaço (não o chamarei aqui de impenetrabilidade ou peso, pois estes são conceitos empíricos)” (KrV A 173 / B 215; grifos nossos) é a mera realidade de algo dado na intuição empírica do espaço, ou ainda, a grandeza intensiva ou o real de uma "sensação em geral" entendido como a "síntese numa consciência empírica em geral" (KrV A 175-176 / B 217; grifos nossos) e que, dessa maneira, opõe-se tão-somente à negação de um algo qualquer dado à sensibilidade sem que com isso se afirme positivamente a afecção dos sentidos externos através desse "algo em geral".

21. Bem entendido, não se trata de algo como uma "força vital", excluída na definição mesma de matéria como um ser extenso inanimado, mas antes apenas das forças dinâmicas de atração e repulsão, que definem as relações recíprocas entre os corpos segundo leis puramente mecânicas. Discutindo a segunda lei da mecânica, Kant torna claro que à inércia corresponde a "ausência de vida" (Leblosigkeit) da "matéria em si mesma", ou seja, faltam a esta "o princípio interno de uma substância finita de se determinar à mudança” e o "desejo (Begehren)" ou "o sentimento de prazer ou desprazer e o apetite (Begierde) ou vontade, que dele depende", todos estes pertencentes apenas a um ser vivo (MAN AA 04: 544). Ainda sobre isso, alguns anos depois, em 1790, Kant também oporia a matéria como "máquina" à finalidade interna presente apenas no organismo. Referimo-nos aqui à distinção feita na Crítica da Faculdade de Julgar entre uma força movente (bewegende) e uma força formadora (bildende) - esta última estaria presente apenas nos organismos, os produtos naturais organizados segundo uma finalidade interna: "Um ser organizado (...) não é simplesmente máquina: esta possui apenas força movente; ele, pelo contrário, possui em si força formadora e na verdade uma tal força que ele comunica aos materiais que não a possuem (ela organiza). Trata-se, pois, de uma força formadora que se propaga a si própria (eine sich fortpflanzende bildende Kraft) [i.e., que não depende dos outros corpos para 'se propagar', como no caso da força movente regida pela lei de inércia - D. K. T.] e que não é explicável tão-somente através da força movente (o mecanismo)” (KU AA 05: 374).

22. "Quando atribuo a um corpo uma força movente (...) conheço-o simultaneamente, isto é, determino o conceito do mesmo como objeto em geral através daquilo que lhe pertence como objeto dos sentidos (...). Considere-se que a força movente que lhe atribuo é uma força de repulsão. Nesse caso o corpo recebe (enquanto eu ainda não coloquei ao seu lado nenhum outro corpo contra o qual ele exerça sua força) um lugar no espaço, mais ainda, uma extensão, isto é, um espaço nele mesmo, e além disso o preenchimento do mesmo através de forças repulsoras das suas partes" (KU AA 05: 482-483; grifo nosso).

23. Cf. KrV A 222-223 / B 269-270: "Caso se quisesse, no entanto, sem emprestar à própria experiência o exemplo de sua conexão, fazer novos conceitos de substâncias, forças e reciprocidades a partir do material que a percepção nos oferece, cair-seia em meras fantasias cuja possibilidade não pode ser indicada por sinal algum, já que a experiência não é nelas assumida como mestra, nem esses conceitos são dela extraídos. Semelhantes conceitos imaginários não podem, como as categorias, receber o caráter de sua possibilidade a priori, enquanto condições de que toda experiência depende, mas sim a posteriori, como conceitos dados através da própria experiência; e a sua possibilidade ou é conhecida a posteriori e empiricamente, ou não é de modo algum conhecida. Uma substância que estivesse permanentemente presente no espaço, ainda que sem preenchê-lo (tal como aquela coisa intermediária entre a matéria e o ser pensante que alguns pretendem ter introduzido), ou um poder fundamental especial de nossa mente para intuir o futuro antecipadamente (em vez de apenas conjecturá-lo), ou ainda uma faculdade da mesma para entrar em comunidade de pensamento com outros seres humanos (por mais distantes que eles estejam): tais são conceitos cuja possibilidade é inteiramente infundada, já que não pode ser fundada na experiência ou em suas conhecidas leis e, sem estas, não passa de uma conjunção arbitrária de pensamentos que, mesmo não contendo qualquer contradição, não pode levantar nenhuma pretensão à realidade objetiva, nem portanto à possibilidade do objeto que se quer aí pensar. No que diz respeito à realidade, é evidente por si mesmo que não se pode pensá-la in concreto sem recorrer à ajuda da experiência, pois ela só pode referir-se à sensação como matéria da experiência e não concerne à forma da relação, com a qual se poderia jogar nas fantasias”. 
24. Na Crítica da Faculdade de Julgar, Kant afirma que uma das possíveis tentativas de explicar a possibilidade interna da matéria como base das forças moventes de atração e repulsão redunda na postulação de um "primeiro motor" que comunica o movimento aos corpos. Trata-se, decerto, de um esforço vão: "eu não possuo absolutamente nenhuma determinação que me possa tornar compreensível a condição de possibilidade do movimento através desse ser [primeiro motor] tomado como princípio” (KU AA 05: 483).

25. Esta é a tese de Peter Plaass, influente comentador dos PPMCN (PLAASS, 1965). Contra Plaass, cf. CRAMER, 1985, p. 154161, e FRIEDMAN, 2001, p. 330n.

26. Mencionemos aqui que esta distinção entre princípio transcendental e princípio metafísico explicitamente aludida na Crítica da Faculdade de Julgar encontra uma correspondência na Crítica da Razão Pura, mais especificamente na oposição realizada na "Estética Transcendental" entre uma "exposição metafísica" e uma "exposição transcendental" dos conceitos de espaço e tempo. Cf. KrV B 37-42. É de se ressaltar que Kant introduziu tal oposição apenas na edição B, ou seja, em 1787, sinalizando com isso, talvez, a mudança por que passaram partes significativas da Crítica da Razão Pura após a publicação dos PPMCN. Voltaremos a isso adiante.

27. Essa peculiaridade dos princípios transcendentais é explicitada na discussão acerca dos princípios dinâmicos na "Analítica dos Princípios" da Crítica da Razão Pura, ou seja, nas "Analogias da Experiência" e nos "Postulados do Pensamento Empírico em Geral". Segundo Kant, estes princípios seriam "regulativos", e não "constitutivos" para a síntese do diverso empírico em geral: "Uma analogia da experiência, portanto, será apenas uma regra segundo a qual a unidade da experiência deve originar-se das percepções (não como percepção mesma, enquanto intuição empírica em geral) e valer como princípio dos objetos (fenômenos) não constitutiva, mas apenas regulativamente. O mesmo vale, porém, para os postulados do pensamento empírico em geral, que em seu conjunto dizem respeito à síntese da mera intuição (forma do fenômeno), da percepção (matéria do fenômeno) e da experiência (relação entre essas percepções) sendo, de fato, princípios apenas regulativos e se diferenciando dos matemáticos, que são constitutivos, não segundo a certeza, que em ambos permanece firme a priori, mas segundo o tipo de evidência, isto é, o que é neles intuitivo (e, portanto, também segundo o tipo de demonstração)" (KrV A 180 / B 222-223). Em outras palavras, os princípios transcendentais apresentam as condições de possibilidade de uma experiência em geral, e não o conteúdo efetivo da mesma, que, no entanto, deve ser sintetizado segundo a regra estipulada por aqueles. "As categorias, ou, dito mais tecnicamente, os princípios (isto é, as categorias mais o tempo) são constitutivos vis-à-vis à experiência possível (isto é, vis-à-vis à forma da experiência, ou ainda, à experiência em geral, o que Kant denomina 'o objeto transcendental = X'); na medida, contudo, em que nada implica a priori que algum conteúdo efetivo venha incluir-se sob essa definição formal da objetividade (implicação a priori que acarretaria que o real fosse intrinsecamente racional, ou seja: a tese do idealismo absoluto), categorias e princípios somente são regulativos com relação às intuições (portanto, com relação às experiências reais), ou, se se prefere, com relação à existência dos fenômenos, a qual, portanto, não pode ser construída a priori” (RENAUT, 1994, p. 317).

28. Bem entendido: o termo "princípio" metafísico se aplica de modo mais apropriado às correspondências entre as categorias de relação, as analogias da experiência e as leis da mecânica. Contudo, o raciocínio empregado até aqui se estende até as demais categorias, ao restante da "Analítica dos Princípios" e às demais partes dos PPMCN, a foronomia, a dinâmica e a fenomenologia - contudo, não nos deteremos nessas questões. O livro de Vuillemin citado acima é exemplar nesse ponto. Além de localizar a física kantiana em um quadro histórico e discutir as modificações por que passou o pensamento de Kant quanto ao tema, o autor mostra passo a passo as correspondências aqui apenas mencionadas. Cf. VUILLEMIN, 1955. Para uma tabela com o esquema das correspondências aludidas acima, cf. ibidem, p. 29.

29. Hoppe (1969, p. 36-41) argumenta que essas modificações introduzidas na segunda edição da Crítica da Razão Pura confundem o papel preciso desempenhado pela dedução transcendental e pelo esquematismo: ora, se uma metafísica da substância corporal é exigida para que seja demonstrada a realidade objetiva das categorias e dos princípios do entendimento puro, que exata função justificatória teriam então uma dedução transcendental e um esquematismo dos conceitos puros do entendimento? Hoppe ainda discute em que medida essa nova postura de Kant fez com que ele alterasse o capítulo sobre os paralogismos, bem como redigisse a nova parte sobre a refutação do idealismo. Veremos na sequência imediata como Vuillemin tem uma opinião semelhante à de Hoppe, se bem que mais elaborada e de conclusões mais abrangentes.

30. VUILLEMIN, 1955, p. 14; 40.

31. LEBRUN, 2002, p. 19ss.

32. Cf. VUILLEMIN, 1955, p. 40ss., nas quais Vuillemin, a exemplo de Cohen, identifica no sistema de princípios a "gênese" da Crítica: "É através dos Princípios que seria necessário ler a Crítica para compreender sua gênese e reproduzir, em nossa reflexão, o movimento imanente de sua arquitetônica” (p. 40). Trata-se, a nosso ver, de um sinal inequívoco de que Vuillemin lê a Crítica 
como, de fato, algo próximo a um "vestíbulo das ciências positivas" e, com isso, escamoteia o problema de uma metafísica pós-tradicional e a reabilitação dos seus objetos par excellence (a saber, Deus, Alma e Liberdade) sob a perspectiva prática, não especulativa.

33. FORUM FÜR PHILOSOPHIE BAD HOMBURG, 1989, p. vII.

\section{REFERÊNCIAS}

ADICKES, E. Kant als Naturforscher. Bd. I-II. Berlin: De Gruyter, 1924.

CAIMI, M. La metafísica de Kant. Buenos Aires: UEBA, 1989.

CASSIRER, E. Das Erkenntnisproblem in der Philosophie und Wissenschaft der neueren Zeit. Bd. I-IV. Darmstadt: WBG, 1999.

COHEN, H. Ethik des reinen Willens. Berlin: Bruno Cassirer, 1907.

CRAMER, K. Nicht-reine synthetische Urteile a priori. Ein Problem der Transzendentalphilosophie Immanuel Kants. Heidelberg: Carl Winter Universitätsverlag, 1985.

FORUM FÜR PHILOSOPHIE BAD HOMBURG (org). “Vorbemerkung”. In: Übergang. Untersuchungen zum Spätwerk Immanuel Kants. Frankfurt am Main: Vittorio Klostermann, 1989.

FRIEDMAN, M. Kant's Construction of Nature: a Reading of the Metaphysical Foundations of Natural Science. Cambridge: Cambridge University Press, 2013.

. "Matter and Motion in the Metaphysical Foundations and the first Critique: The Empirical Concept of Matter and the Categories”. In: FULDA, H. F. - STOLZENBERG, J. (orgs). Architektonik und System in der Philosophie Kants. Hamburg: Felix Meiner, 2001.

HEGEL, G. W. F. Wissenschaft der Logik, I. Frankfurt: Suhrkamp, 2000.

. Enzyklopädie der philosophischen Wissenschaften, II. Frankfurt: Suhrkamp, 2001.

HOPPE, H. Kants Theorie der Physik. Eine Untersuchung über das Opus postumum von Kant. Frankfurt: Vittorio Klostermann, 1969.

KANT, I. Kants gesammelte Schriften: Herausgegeben von der Deutschen Akademie der Wissenschaften, anteriormente Königlichen Preussischen Akademie der Wissenschaften, Berlin: Walter de Gruyter, 190228,29 vols.

. A Metafísica dos Costumes. Petrópolis: Vozes, 2013.

. Crítica da Faculdade do Juízo. Rio de Janeiro: Forense Universitária, 1995.

. Crítica da Razão Prática. São Paulo: Martins Fontes, 2002. 
. Crítica da Razão Pura. Petrópolis: Vozes, 2012.

. Fundamentação da Metafísica dos Costumes. São Paulo: Discurso Editoral e Barcarolla, 2009.

. Os Progressos da Metafísica. Lisboa: Edições 70, 1995.

.Primeiros Princípios Metafísicos da Ciência da Natureza. Lisboa: Edições 70, 1990.

. Prolegômenos a toda a Metafísica Futura. Lisboa. Edições 70, 2003.

KÖHNKE, K. C. Entstehung und Aufstieg des Neukantianismus: die deutsche Universitätsphilosophie zwischen Idealismus und Positivismus. Frankfurt: Suhrkamp, 1993.

LEBRUN, G. Kant e o fim da metafísica. São Paulo: Martins Fontes, 2002.

PLAASS, P. Kants Theorie der Naturwissenschaft: eine Untersuchung zur Vorrede von Kants "Metaphysischen Anfangsgründen der Naturwissenschaft". Göttingen: Vandenhoeck \& Ruprecht, 1965.

RENAUT, A. "Présentation”. In: KANT, I. Métaphysique des moeurs I. Paris: Flammarion, 1994.

SCHELLING, F. W. J. Ideen zu einer Philosophie der Natur. Stuttgart: Frommann-Holzboog, 1994.

TERRA, R. Passagens. Estudos sobre a filosofia de Kant. Rio de Janeiro: Editora UFRJ, 2003.

TREVISAN, D. K. "Sentidos de metafísica na filosofia crítica de Kant". In: Studia Kantiana (Rio de Janeiro), vol. 17, p. 104-125, 2014.

VUILLEMIN, J. Physique et métaphysique kantiennes. Paris: P.U.F., 1955.

WOLFF, C. Einleitende Abhandlung über Philosophie im allgemein. Stuttgart: Frommann-Holzboog, 2006. . Vernünftige Gedanken von Gott, der Welt und der Seele des Menschen, auch allen Dingen überhaupt.

In: Gesammelte Werke. Jean École et al. (eds.). Hildesheim-Zürich-New York: Georg Olms Verlag, 1962. 